DOI: https://doi.org/10.31933/dijemss.v2i4 Received: $10^{\text {th }}$ January 2021, Revised: $15^{\text {th }}$ February 2021, Publish: $25^{\text {th }}$ April 2021

\begin{tabular}{|c|c|c|}
\hline PUNASTI & $\begin{array}{l}\text { DIJEMSS } \\
\text { DINASTI INTERNATIONAL JOURNAL } \\
\text { OF EDUCATION MANAGEMENT AND } \\
\text { SOCIAL SCIENCE }\end{array}$ & $\begin{array}{r}\text { https://dinastipub.org/DIJEMSS } \\
\text { editor@dinastipub.org } \\
08117401455\end{array}$ \\
\hline
\end{tabular}

\title{
IMPROVING CUSTOMER SATISFACTION THROUGH THE IMPLEMENTATION OF THE SMILE AND GREET CAMPAIGN
}

\author{
Akmal Sutja ${ }^{1}$, Robi Hendra ${ }^{2}$, Rio Dezaneru ${ }^{3}$, Mohamad Muspawi ${ }^{4 *}$, Yantoro Yantoro ${ }^{5}$ \\ 1) Universitas Jambi, Jambi, Indonesia \\ 2) Universitas Jambi, Jambi, Indonesia \\ 3) Universitas Jambi, Jambi, Indonesia \\ 4) Universitas Jambi, Jambi, Indonesia, muspawi01@gmail.com \\ 5) Universitas Jambi, Jambi, Indonesia \\ *Corresponding Author: muspawi01@gmail.com ${ }^{4)}$
}

\begin{abstract}
The ability of library staff in building visitors' trust and assurance determines customer satisfaction and service quality. The purpose of this research is to find out the improvement of customer satisfaction through the application of smiling and greeting in circulation service at the library of Jambi University. This research is a service action research. The subjects were 30 students of Jambi University. This research was conducted in two cycles, using steps in action research which included planning, action, evaluation and reflection. This research was conducted collaboratively between researchers as observers and library staff as service providers. Data collection techniques used in this study include questionnaires, observations, interviews, and check lists. The result of this study obtained the percentage of customer satisfaction before the implementation of service is $48 \%$ with a moderate level, then increased by $17 \%$ to $67 \%$ with a high level in the first cycle and in the second cycle increased by $14 \%$ to $81 \%$ which is the highest level achieved due to morning greetings with hands folded in front of the chest, smiling teeth and small talks that ask questions related to customers' personal.
\end{abstract}

Keywords: Customer Satisfaction, Smile, Greet.

\section{INTRODUCTION}

The quality of a nation can be seen from how high its reading interest is, according to a UNSECO survey quoted on KOMPAS.com stated that based on the Most Literate Nation In the World study conducted by the Central Connecticut State University in March 2016, Indonesia ranked the second lowest which was on 60th out of 61 countries about reading interest (Gewati, 2016 [Trans.]). It is sad considering that we are a big nation. However, we have to accept this fact and use this as a motivation to improve this matter by optimizing the role of libraries as literacy providers.

The library as described in Law No. 43 of 2007 is a professional institution that manages the collection of written, printed and recorded works with a standardized system to meet the educational, research, preservation, information, and recreation needs of the visitors. However, according to Bafadal (2015), the role of library is not merely what has been mentioned above, it is also expected that students will gradually grow their reading interest by the existence of 
library. Library nowadays has a significant role in increasing the reading interest of children of the nation, but in fact the library especially the campus is still lack of visitors even though the campus library should have regular visitors who are students at the university. Thus, it raises a question of why this issue can happen.

After preliminary observation at the library of Jambi University and interviews with several students, some phenomena that caused the lack of students visiting the library were seen, namely (1) the staff uses impolite language (2) staff sometimes use high-pitched voices to visitors (3) the facial expression of staff causes students to be less confident (4) the circulation staff are less communicative, then it makes visitors feel uncomfortable. It can be concluded that the core of this issue is the quality of circulation service.

Rinala, Yudana, and Natajaya (2013) stated that educational institutions, including libraries, are public organizations. In order to provide such good quality of services, it is necessary to make some changes to the existing resources in the form of improving service devices and maximizing the role of staff. The step that need to be taken to improve the quality of service is optimizing the human resources to support the continuity of services. Service is considered as good if the perceived service is equal or exceeds the quality of service expected. This kind of service is perceived as satisfying and ideal service.

Quality of service should not be seen from the management perspective only, but it has to involve the customers, or in this case is library visitors. Particularly in campus which is in line with what is stipulated in the Government Regulation of the Republic of Indonesia No. 30 of 1990 concerning Higher Education Article 106 no.1 students have the rights to: 1). Use academic freedom and responsibility to demand and study knowledge in accordance with applicable norms and ethics in an academic environment; 2) Obtain the best teaching and services in terms of academic field based on their interests, talents, hobbies and abilities; 3 ) utilize the university facilities to run the learning process smoothly.

Therefore, the library circulation service procedure needs to be improved as it has been stated in Government Regulation No. 30 of 1990 Article 106 states that students have the right to obtain academic services as well as possible and utilize university facilities for the sake of smooth learning process. It means that the library has to provide the best service for students to be comfortable and pleased when visiting the library.

Researchers believe that circulation service is important in increasing customer satisfaction by comparing to a study conducted by Novianti, Mindarti, \& Hermintatik (2015) stating that assurance variables which include politeness, safety and employee knowledge have a significant influence on customer satisfaction. $h>$ ie $2.119>1.664$ with a significance of 0.037 $<0.05$. Significance value that is smaller than 0.05 shows that $\mathrm{Ha}$ is accepted and $\mathrm{Ho}$ is accepted which means Assurance of service has a positive and significant effect.

In contrast, Widaryono (2016) stated that the attitude of library staff of Vocational School High School PP (SMK-PP) Kupang in serving visitors shows that it has met the minimum expectations of visitors, but still needs some improvements. Looking at the dimensional data analysis affect of service which includes knowledge, insight, ability, and friendliness of library staff in serving library visitors shows that it has met the minimum service level, which is 5.54 and the level of service performance provided with a score of 6.13. The AG score is positive at 0.28 , which indicates that the library meets the visitors' minimum expectations. This dimension places more emphasis on the librarian side, it appears that the library visitors' are not satisfied with the ability, attitude, and mentality of the library staff. This indicates that there is a necessity to increase the ability and attitude of staff in providing services to visitors.

From these two studies, it can be seen that the different results obtained due to different services provided. Therefore, the result of the first study is very significant while the other is on the minimum level of service which only meets the expectation. This coincides with Istiana's 
statement (2014) that said visitors want good quality of services, hence it is necessary to prepare library staff to have the skills or abilities because if visitors do not understand the tasks of the service section, it will affect the service quality in a bad way and won't fulfill visitors' expectations. Thus, it can be concluded that service satisfaction is directly proportional or exceeds the quality of service expected by customers / visitors.

After reviewing these findings, looking at the phenomena occurs in the society, considering the very limited publications related to this matter, and problems in the field related to the application of theory that do not work properly just like those two contradictory studies above, researchers were interested in conducting an action research to improve students' satisfaction in circulation service through the application of the Smile and Greet campaign in the library of Jambi University in particular. Researchers decided to conduct an action research as there are only a few publications using action research in the field of Educational Administration. This research looks at the problems and directly creates solutions for the issues that really happen in the reality. The procedures used in this research can create such a guarantee of the service quality of all libraries to be satisfying and hopefully this research can enhance options available for the academics of Educational Administration in order to choose their type of research. circulation service is chosen because the interaction between staff and visitors occur most frequent at the time of circulation, hence the problems can be seen and observed. Therefore, the result of this study is expected to provide solutions to improve the quality of service and intensity of students visiting the library in time to come.

\section{RESEARCH METHOD}

This research was located in the library of Jambi University and was completed on June $19^{\text {th }}-$ July $19^{\text {th }}, 2019$. This type of research is a service action research. The subjects of this study were 30 Jambi University students. This research was conducted in two cycles, using steps in action research which included planning, action, evaluation and reflection. This research was conducted collaboratively between researchers as observers and library staff as service providers. Data collection techniques used in this study included questionnaires, observations, interviews, and check lists. The technique used for data analysis in this study was the percentage description technique. For performance indicators from quantitative data, it was set the criteria that the more visitor satisfaction in library circulation service increase, students in the higher category show the criteria for increasing satisfaction in this service action research.

\section{RESULT AND DISCUSSION}

\section{Result}

The comparison of library staff activities between each cycle

The increase of library staff activities of this research can be seen in the table below:

Table 1. The Comparison of Library Staff Activities between each Cycle

\begin{tabular}{|c|c|c|c|c|c|c|c|c|c|c|c|c|}
\hline \multirow{2}{*}{ No } & \multirow{2}{*}{$\begin{array}{c}\text { Respondent } \\
\text { Code }\end{array}$} & \multicolumn{3}{|c|}{ Initial Finding } & \multicolumn{3}{|c|}{ Cycle I } & \multirow[t]{2}{*}{ Increase } & \multicolumn{3}{|c|}{ Cycle II } & \multirow{2}{*}{ Increase } \\
\hline & & $\Sigma$ & $\%$ & Level & $\Sigma$ & $\%$ & Level & & $\Sigma$ & $\%$ & Level & \\
\hline 1 & S-1 & 1 & 3 & $\begin{array}{l}\text { Very } \\
\text { Low }\end{array}$ & 24 & 80 & High & 77 & 27 & 90 & $\begin{array}{l}\text { Very } \\
\text { High }\end{array}$ & 10 \\
\hline 2 & S-2 & 14 & 47 & Mod & 29 & 97 & \begin{tabular}{|l|} 
Very \\
High \\
\end{tabular} & 50 & 29 & 97 & $\begin{array}{l}\text { Very } \\
\text { High }\end{array}$ & - \\
\hline 3 & $\mathrm{~S}-3$ & 7 & 23 & Low & 28 & 93 & \begin{tabular}{|l|} 
Very \\
High \\
\end{tabular} & 70 & 30 & 100 & $\begin{array}{l}\text { Very } \\
\text { High }\end{array}$ & 7 \\
\hline
\end{tabular}




\begin{tabular}{|c|c|c|c|c|c|c|c|c|c|c|c|c|}
\hline 4 & S-4 & 21 & 70 & High & 26 & 87 & High & 17 & 29 & 97 & $\begin{array}{l}\text { Very } \\
\text { High }\end{array}$ & 10 \\
\hline 5 & S-5 & 30 & 100 & Mod & 30 & 100 & $\begin{array}{l}\text { Very } \\
\text { High }\end{array}$ & - & 30 & 100 & $\begin{array}{l}\text { Very } \\
\text { High }\end{array}$ & - \\
\hline 6 & S-6 & 25 & 83 & Low & 28 & 93 & $\begin{array}{l}\text { Very } \\
\text { High }\end{array}$ & 10 & 30 & 100 & $\begin{array}{l}\text { Very } \\
\text { High }\end{array}$ & 7 \\
\hline 7 & S-7 & 5 & 17 & Low & 0 & - & $\begin{array}{l}\text { Very } \\
\text { Low }\end{array}$ & 17 & 26 & 87 & High & 87 \\
\hline Percentage & & & 47 & & & 93 & & & & 97 & & 3 \\
\hline
\end{tabular}

Based on table 1, it can be seen that the initial finding of activities undertaken by library staff in the borrowing and returning circulation service is $47 \%$ and in the cycle I of $93 \%$, there is an increase of $47 \%$. While the cycle II of library staff activities in serving customers is $97 \%$ there is $4 \%$ increase compared to cycle I.

\section{The Comparison of Customer Activities between Cycles}

Along with the increase of library staff activities, customers activities in receiving the borrowing and returning circulation service has also increased as shown in the table below:

Table 2 The Comparison of Customers Activities between Cycles

\begin{tabular}{|c|c|c|c|c|c|c|c|c|c|c|c|c|}
\hline \multirow{2}{*}{ No } & \multirow{2}{*}{$\begin{array}{l}\text { Percentage } \\
\text { Code }\end{array}$} & \multicolumn{3}{|c|}{$\begin{array}{l}\text { Initial } \\
\text { Finding }\end{array}$} & \multicolumn{3}{|c|}{ Cycle I } & \multirow[t]{2}{*}{ Increase } & \multicolumn{3}{|c|}{ Cycle II } & \multirow[t]{2}{*}{ Increase } \\
\hline & & $\Sigma$ & $\%$ & Level & $\Sigma$ & $\%$ & Level & & $\Sigma$ & $\%$ & Level & \\
\hline 1 & S-1 & 22 & 73 & High & 24 & 80 & High & 7 & 28 & 93 & Very High & 13 \\
\hline 2 & $\mathrm{~S}-2$ & 1 & 3 & Low & 17 & 57 & High & 53 & 29 & 97 & Very High & 40 \\
\hline 3 & $S-3$ & 7 & 23 & High & 28 & 93 & Very High & 70 & 30 & 100 & Very High & 7 \\
\hline 4 & S-4 & 13 & 43 & Mod & 19 & 63 & HIgh & 20 & 27 & 90 & Very High & 27 \\
\hline Percentage & & & 33 & & & 72 & & 38 & & 95 & & 23 \\
\hline
\end{tabular}

Table 2 shows the initial finding of the activities carried out by visitors when receiving borrowing and returning circulation service of $33 \%$, and in cycle I of $72 \%$, there is an increase for $38 \%$. While for cycle II is $95 \%$, there is $23 \%$ increase compared to cycle I.

\section{The Comparison of Results from Customer Satisfaction Questionnaire from each cycle}

The following table shows the results of customer satisfaction questionnaire from each cycle:

Tabel 3 The Comparison of Per-Indicator Questionnaire Results between cycles

\begin{tabular}{|c|c|c|c|c|c|c|c|c|c|c|c|}
\hline \multirow{2}{*}{ Item No. } & \multicolumn{3}{|c|}{ Initial Finding } & \multicolumn{3}{|c|}{ Cycle I } & \multirow[t]{2}{*}{ Increase } & \multicolumn{3}{|c|}{ Cycle II } & \multirow[t]{2}{*}{ Increase } \\
\hline & $\Sigma$ & $\%$ & Level & $\Sigma$ & $\%$ & Level & & $\Sigma$ & $\%$ & Level & \\
\hline \multicolumn{12}{|c|}{ Reality Indicator } \\
\hline
\end{tabular}




\begin{tabular}{|c|c|c|c|c|c|c|c|c|c|c|c|}
\hline 1 & 42 & 47 & Mod & 71 & 79 & High & 32 & 83 & 92 & $\begin{array}{l}\text { Very } \\
\text { High }\end{array}$ & 13 \\
\hline 2 & 25 & 28 & Low & 56 & 62 & High & 34 & 73 & 81 & High & 19 \\
\hline 3 & 35 & 39 & Low & 68 & 76 & High & 37 & 76 & 84 & High & 9 \\
\hline 4 & 64 & 71 & High & 71 & 79 & Mod & 8 & 81 & 90 & $\begin{array}{l}\text { Very } \\
\text { High }\end{array}$ & 11 \\
\hline 5 & 53 & 59 & Mod & 72 & 80 & High & 21 & 80 & 89 & $\begin{array}{l}\text { Very } \\
\text { High }\end{array}$ & 9 \\
\hline 6 & 70 & 78 & High & 60 & 67 & High & -11 & 74 & 82 & High & 16 \\
\hline Increase & & 53 & & & 77 & & 24 & & 87 & & 9 \\
\hline \multicolumn{12}{|c|}{ Interest Indicator } \\
\hline 7 & 44 & 49 & Mod & 64 & 71 & High & 22 & 81 & 90 & $\begin{array}{l}\text { Very } \\
\text { High }\end{array}$ & 19 \\
\hline 8 & 41 & 46 & Mod & 54 & 60 & High & 14 & 67 & 74 & High & 14 \\
\hline 9 & 33 & 37 & Low & 39 & 43 & Mod & 7 & 59 & 66 & High & 22 \\
\hline 10 & 24 & 27 & Low & 44 & 49 & Mod & 22 & 54 & 60 & High & 11 \\
\hline Increase & & 41 & Mod & & 54 & Mod & 13 & & 70 & High & 16 \\
\hline & \multicolumn{11}{|c|}{ Overall Result } \\
\hline Increase & & 46 & Mod & & 69 & High & 23 & & 83 & High & 14 \\
\hline
\end{tabular}

From table 3, it can be seen that the initial finding of the activities carried out by customers when receiving borrowing and returning circulation service had an average value of $48 \%$ with the reality indicator value of $53 \%$ and the interest indicator of $41 \%$. In the cycle I the average value of customer satisfaction $67 \%$ with a reality indicator value of $77 \%$ and interest indicator of $54 \%$, there is an increase for $23 \%$. While in cycle II customer activity when receiving circulation service, the average value of customer satisfaction is $81 \%$ with a reality indicator value of $87 \%$ and an interest indicator of $70 \%$, an increase of $14 \%$ compared to cycle I.

Table 4 The Comparison of Per-Sample Questionnaire Results between Cycles

\begin{tabular}{|c|c|c|c|c|c|c|c|c|c|c|c|c|}
\hline \multirow{2}{*}{ No } & \multirow{2}{*}{$\begin{array}{l}\text { Respondent } \\
\text { Code }\end{array}$} & \multicolumn{3}{|c|}{ Initial Finding } & \multicolumn{3}{|c|}{ Cycle I } & \multirow[t]{2}{*}{ Increase } & \multicolumn{3}{|c|}{ Cycle II } & \multirow{2}{*}{ Increase } \\
\hline & & $\sum$ & $\%$ & Level & $\sum$ & $\%$ & Level & & $\sum$ & $\%$ & Level & \\
\hline 1 & S-1 & 15 & 50 & Mod & 19 & 63 & High & 13 & 20 & 67 & High & 3 \\
\hline 2 & S-2 & 9 & 30 & Low & 20 & 67 & High & 37 & 27 & 90 & Very High & 23 \\
\hline 3 & S-3 & 20 & 67 & High & 24 & 80 & High & 13 & 29 & 97 & Very High & 17 \\
\hline 4 & S-4 & 16 & 53 & Mod & 17 & 57 & Mod & 3 & 22 & 73 & High & 17 \\
\hline 5 & S-5 & 13 & 43 & Mod & 21 & 70 & High & 27 & 22 & 73 & High & 3 \\
\hline 6 & S-6 & 9 & 30 & Low & 18 & 60 & High & 30 & 23 & 77 & High & 17 \\
\hline 7 & S-7 & 23 & 77 & High & 24 & 80 & High & 3 & 29 & 97 & Very High & 17 \\
\hline 8 & $\mathrm{~S}-8$ & 20 & 67 & High & 23 & 77 & High & 10 & 30 & 100 & Very High & 23 \\
\hline 9 & S-9 & 11 & 37 & Low & 20 & 67 & High & 30 & 26 & 87 & High & 20 \\
\hline 10 & S-10 & 10 & 33 & Low & 20 & 67 & High & 33 & 24 & 80 & High & 13 \\
\hline 11 & $S-11$ & 15 & 50 & Mod & 19 & 63 & High & 13 & 26 & 87 & High & 23 \\
\hline 12 & S-12 & 12 & 40 & Low & 14 & 47 & Mod & 7 & 24 & 80 & Mod & 33 \\
\hline
\end{tabular}




\begin{tabular}{|c|c|c|c|c|c|c|c|c|c|c|l|c|}
13 & S-13 & 20 & 67 & High & 25 & 83 & High & 17 & 30 & 100 & Very High & 17 \\
\hline 14 & S-14 & 15 & 50 & Mod & 17 & 57 & Mod & 7 & 17 & 57 & Mod & - \\
\hline 15 & S-15 & 16 & 53 & Mod & 20 & 67 & High & 13 & 23 & 77 & High & 10 \\
\hline 16 & S-16 & 12 & 40 & Low & 19 & 63 & High & 23 & 24 & 80 & High & 17 \\
\hline 17 & S-17 & 21 & 70 & High & 23 & 77 & High & 7 & 27 & 90 & Very High & 13 \\
\hline 18 & S-18 & 16 & 53 & Mod & 22 & 73 & High & 20 & 27 & 90 & Very High & 17 \\
\hline 19 & S-19 & 15 & 50 & Mod & 22 & 73 & High & 23 & 30 & 100 & Very High & 27 \\
\hline 20 & S-20 & 10 & 33 & Low & 19 & 63 & High & 30 & 21 & 70 & High & 7 \\
\hline 21 & S-21 & 15 & 50 & Mod & 22 & 73 & High & 23 & 26 & 87 & High & 13 \\
\hline 22 & S-22 & 15 & 50 & Mod & 23 & 77 & High & 27 & 28 & 93 & Very High & 17 \\
\hline 23 & S-23 & 15 & 50 & Mod & 19 & 63 & High & 13 & 20 & 67 & High & 3 \\
\hline 24 & S-24 & 11 & 37 & Low & 21 & 70 & High & 33 & 22 & 73 & High & 3 \\
\hline 25 & S-25 & 20 & 67 & High & 24 & 80 & High & 13 & 24 & 80 & High & - \\
\hline 26 & S- 26 & 7 & 23 & Low & 14 & 47 & Mod & 23 & 16 & 53 & Mod & 7 \\
\hline 27 & S-27 & 14 & 47 & Mod & 15 & 50 & Mod & 3 & 25 & 83 & Mod & 33 \\
\hline 28 & S-28 & 12 & 40 & Low & 19 & 63 & High & 23 & 24 & 80 & High & 17 \\
\hline 29 & S-29 & 13 & 43 & Mod & 18 & 60 & High & 17 & 21 & 70 & High & 10 \\
\hline 30 & S-30 & 11 & 37 & Low & 18 & 60 & High & 23 & 22 & 73 & High & 13 \\
\hline
\end{tabular}

Based on table 4, the percentage frequency of respondents' answers toward 10 questions regarding customer satisfaction has increased from the previous initial finding which is $48 \%$ and Cycle I is $67 \%$, hence it increased for $17 \%$. While the percentage of Cycle II is $81 \%$, which means it has increased for $14 \%$ from Cycle I. In addition, questionnaire data are described in order to see the level of satisfaction between cycles in the figure below:

\section{The Comparison graph of customer satisfaction between cycles}

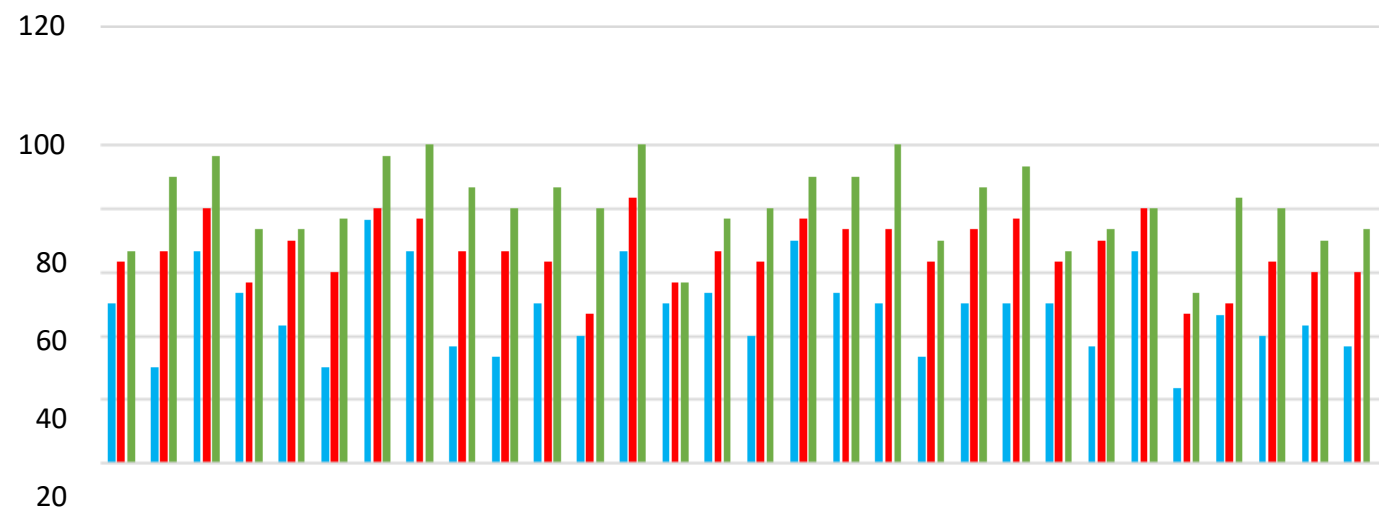

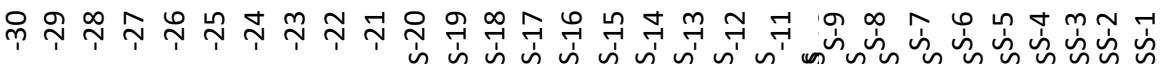

- Initial Finding " Cycle I $\|$ Cycle II

Figure 1. Comparison graph of customer satisfaction between cycles 


\section{Discussion}

Based on the result of customer satisfaction research through the application of The Smile and Greet Campaign in circulation service at the library of Jambi University shows that customer satisfaction can be improved through the application of The Smile and Greet Campaign. The application of this campaign in circulation service in this study was carried out in 2 cycles. Cycle II was carried out as a completion of cycle I. This research was participated by 30 respondents and researchers as observers and assisted by library staff as collaborators. Respondents taken are non-random samples chosen by researchers who they encountered at the research place, then they were asked their willingness to participate in each cycle of this action research.The customer satisfaction in initial finding before given the information service has an average of $48 \%$ which categorized as moderate and the average value of the Reality indicator of $53 \%$ and interest indicator $41 \%$.

After the Smile and Greet was applied in circulation service in the cycle I by giving good morning / afternoon greeting, smiling, and inviting visitors to sit down then filling customer satisfaction questionnaires, the analysis result shows that there is an increase in customer satisfaction for $17 \%$, the average level of customer satisfaction increased to $67 \%$ which is categorized as high and the average value of the reality indicator is $77 \%$ and the interest indicator is $54 \%$.

Although there has been an increase in the level of customer satisfaction after the implementation of Smile and Greet in circulation service in the first cycle, there are still some customers that show increases insignificantly. Moreover, researchers also feel that customers still did not respond actively when circulation service took place. Therefore, it was necessary for researchers to do one more cycle which is cycle II. In this second cycle, the researchers and collaborators agreed to The Smile and Greet with a smile that showed teeth, say good morning accompanied by hands folded in front of the chest, and followed by small talks after the staff asking visitors' needs and processing it at the time.

From the analysis of customer satisfaction questionnaires in the second cycle, the average level of customer satisfaction increased to $81 \%$ categorized as high with a reality indicator value of $87 \%$ and an interest indicator of $70 \%$. Referring to the results of the application of Smile and Greet in circulation service in cycle I and cycle II, overall customer satisfaction has increased. This is proven by the results of the descriptive calculation of the percentage of customer satisfaction questionnaires which shows a significant increase. Prior to the Smile and Greet implementation in circulation service, the average level of customer satisfaction is moderate, but it has been high after the campaign implemented. Although the overall customer satisfaction is high on the interest indicator for $70 \%$, it does not meet the expectation of research performance indicator. After the researchers crosschecked by interviewing several respondents, it was found out that this happened due to the lack of book collection and the disordered library layout that caused the difficulty in looking for books.

In spite of that, improvement can be found not only from the result of the percentage descriptive calculation of customer satisfaction questionnaires, but it can also be seen from the result of observation carried out during the implementation of Smile and Greet activities in circulation service with researchers as observers. Those improvements include easily smiling visitors who actively respond to the staff and they look more comfortable when receiving service and thank the staff. 
Table 5 The recapitulation of customer satisfaction questionnaire results

It shows that the satisfaction

in

\begin{tabular}{|l|r|r|r|l|l|}
\hline \multicolumn{2}{|c|}{ Initial Finding } & \multicolumn{2}{c|}{ Cycle I } & \multicolumn{2}{c|}{ Cycle II } \\
\hline$\Sigma$ & $\%$ & $\Sigma$ & $\%$ & $\Sigma$ & $\%$ \\
\hline \multicolumn{2}{|c|}{$48 \%$} & \multicolumn{2}{|c|}{$67 \%$} & \multicolumn{2}{|c|}{$81 \%$} \\
\hline
\end{tabular}

level of customer circulation service at the Library of Jambi University increased after the implementation of the Smile and Greet. In other words, customer satisfaction in circulation service can be improved through the application of this campaign. This proves the statement from Mowen and Michael (2002) that one of factors that determines customer satisfaction is the way librarians interact with customers. This is in line with the results of Widiana \& Febrianto's research (2013) which shows that the service of Smile and Greet has an influence on supermarket consumer satisfaction. This is also in accordance with Kurniasih's research (2018), Pandita (2017), Nurendah \& Mulyana (2013), Ningrum (2014). Wood (2009, p.6) said costumer satisfaction is Customer satisfaction is the main focus for evaluating the products and services of an institution in order to measure the achievement of its objectives. Four kinds of customer expectations: 1. Equitable performance, 2. Ideal performanc, 3. Expected performance, 4. Adequate expectation.

\section{CONCLUSION AND SUGGESTION Conclusion}

Circulation service is not limited to borrowing and returning service only. It is also a place for direct interaction between staff and visitors where the ability of frontline staff to gain trust and assurance of visitors determines customer satisfaction and service quality. Customer satisfaction is a very important element which is used as a benchmark for consumer interest in continuing to use goods or services from a company including library. In cycle 1 , the success is $67 \%$ with a reality indicator of $77 \%$ and an interest indicator of $54 \%$ these due to the use of greetings, smile and inviting visitors to sit down. In cycle 2 it reached $81 \%$ with $87 \%$ of reality indicator and $70 \%$ interest indicator which were achieved by using good morning greetings with hands folded in front of chest, smiling with teeth and small talks by asking questions related to customer personal. In this case, reality indicator has met the expectations of the research performance indicator, but not with the interest indicator. It turns out that the lack of book collection and the disordered library layout are the causes of the problem.

\section{Suggestion}

Based on the result and conclusion of this study, the researchers suggest several ideas to end this paper: 1) For Library Staff. The library staff should always implement Smile and Greet in their services, especially for circulation service in accordance with visitor needs in order to increase their satisfaction. 2) For the Library. It is essential to Improve and develop the Smile and Greet procedures in services of the library, particularly for the implementation of circulation service in order to solve problems and in accordance with this research finding, library layout should be neatly arranged and the collection should be enriched in order to increase visitor satisfaction. 3) For fellow researchers. Those who want to analyze the same problem should be more careful and dig deeper the theories related to increasing customer satisfaction through the application of the Smile and Greet campaign in circulation service, complete the lacking areas of this research and find some alternatives to increase customer satisfaction which has not been covered in this study yet in order to obtain better result. 


\section{REFERENCES}

Bafadal, I. 2015. Pengelolaan Perpustakaan Sekolah. Jakarta: Bumi Aksara

Gewati, M. 2016. Minat Baca Indonesia Ada di Urutan ke-60 Dunia. Kompas.com. https://edukasi.kompas.com/read/2016/08/29/07175131/minat.baca.indones ia.ada.di.urutan.ke-60.dunia. 21-01-2019

Kurniasih, N. 2018. Analisis Pengaruh Pelayanan Perpustakaan Terhadap Kepuasan Pengguna Perpustakaan Di Institut Agama Islam Imam Ghozali. Jurnal Tawadhu'. Vol.2 No.1 Istiana, P. 2014. Layanan Perpustakaan. Yogyakarta: Penerbit Ombak Mowen, J.C., Michael, M. 2002. Perilaku konsumen. Jakarta: Erlangga.

Ningrum, R.F. 2014. Pengaruh Pelayanan Perpustakaan Terhadap Kepuasan Pengunjung Di Perpustakaanuniversitas Muhammadiyah Surakarta. Skripsi Teknik Industri. Universitas Muhamadiyah Surakarta. http://eprints.ums.ac.id/30483/11/naskah.pdf

Novianti, H.T., Mindarti, L.I., Hermintatik. 2015. Pengaruh Kualitas Pelayanan Terhadap Kepuasan Pemustaka. Jurnal Administrasi Publik (JAP), Vol. 3: 789-791.

Nurendah, Y., Mulyana, M. 2013. Analisis Pengaruh Kualitas Pelayanan Perpustakaan Terhadap Kepuasan dan Hubungannya dengan Loyalitas Mahasiswa. Jurnal Ilmiah Manajemen Kesatuan Vol. 1 No. 1, 2013 pp. 93-112

Pandita, A. 2017. Pengaruh Kualitas Pelayanan Terhadap Kepuasan Pemustaka Di Upt Perpustakaan Universitas Negeri Makassar. Skripsi Ilmu Perpustakaan. UIN Alauiddin Makasar. http://repositori.uinalauddin. ac.id/1358/1/ANDI\%20PANDITA\%20pdf.pdf

Rinala. I.N.,Yuana. I.M., \& Natajaya. I.N. 2013. Pengaruh Kualitas Pelayanan Akademik Terhadap Kepuasan dan Loyalitas Mahasiswa pada Sekolah Tinggi Pariwisata Nusa Dua Bali. Jurnal Program Pascasarjana Universitas Pendidikan Genesha Volume 4 Tahun 2013.

Widaryono, 2016. Kualitas Layanan Perpustakaan Smk-Pp Negeri Kupang Dalam Perspektif Libqual. Jurnal Perpustakaan Pertanian. Vol. 25 No. 2:

55-62. DOI: 10.21082/jpp.v25n2.2016.p55-62.

Widiana, H.S., Febrianto, M.R. 2013. Efek Pelayanan Senyum, Salam, Sapa Petugas Kasir Terhadap Kepuasan Konsumen Supermarket. Jurnal Psikologi Undip. Vol.12 No.1: 20-31.

Wood, I. 2009. Layanan Pelanggan. Yogyakarta: Graha Ilmu. 